\title{
LONG-TERM BED PLANTING EFFECT ON STABILIZING PRODUCTIVITY OF RICE AND WHEAT IN A DROUGHT PRONE AREA OF BANGLADESH
}

\author{
M. Ilias Hossain ${ }^{1}$, M. I. Hossain ${ }^{2}$, M. R. I Mondal ${ }^{3,}$ M. K. Sultan ${ }^{4}$, M. Gathala ${ }^{5}$ and T. P Tiwary ${ }^{5}$ \\ ${ }^{1}$ Senior Scientific Officer (Agronomy), ${ }^{2}$ Principal Scientific Officer (Agril. Engg.), ${ }^{3}$ Director General and \\ ${ }^{4}$ Director (Research) of Bangladesh Agricultural Research Institute, Gazipur and \\ ${ }^{5}$ Cropping System Agronomists, CIMMYT Bangladesh \\ Corresponding author: iliasrwrc@gmail.com
}

Key words: Bed planting, cropping system, productivity, sustainable, drought

\begin{abstract}
The systems productivity, soil fertility and $\mathrm{N}$ use efficiency were evaluated in a drought area of Rajshahi under five $\mathrm{N}$ fertilizer levels $(0,40,80,100$ and $120 \% \mathrm{~N}$ of the recommended dose, two straw retention (SR) (0 and 30\%) and two tillage options [raised bed and conventional tillage (CT)] in a long term bed planting experiment with Rice-Wheat (RW) systems. The findings revealed that the permanent raised beds (PRB) with 30\% straw retention had the highest productivity for all the three crops in the sequence. Within each $\mathrm{N}$ rate the total system (ricewheat-mungbean) productivity was higher with $30 \%$ SR on PRB and the least in CT with $0 \%$ SR. At $80 \%$ of recommended fertilizer $\mathrm{N}$ rate, mean annual system productivity was $12.8 \mathrm{t} \mathrm{ha}^{-1}$ for PRB with $30 \%$ SR, $11.2 \mathrm{t} \mathrm{ha}^{-1}$ with PRB on $0 \%$ SR and $10.3 \mathrm{t} \mathrm{ha}{ }^{-1}$ with CT without straw. N uptake and use efficiency increased with increasing $\mathrm{N}$ levels with bed planting up to $120 \% \mathrm{~N}$ application $\left(120 \mathrm{~kg} \mathrm{~N} \mathrm{ha}^{-1}\right)$ in wheat, both $100 \%\left(80 \mathrm{~kg} \mathrm{~N} \mathrm{ha}^{-1}\right)$ in rice and $\left(20 \mathrm{kgN} \mathrm{ha}^{-1}\right)$ in mungbean for all the years. System productivity in $\mathrm{N}$ unfertilized plots increased when straw was retained. The results suggest that $\mathrm{N}$ fertilizer rates can be reduced when straw is retained. Soil organic matter in surface soil layers of the PRB had increased by $0.72 \%$ after eight years (8 ricewheat-mungbean crop cycles) with $30 \%$ SR. It may be inferred that straw retention is an important component of soil management and may have long term positive impacts on soil quality compared with conventional tillage with $0 \%$ SR. The combination of PRB with nutrients and residues retained appeared to be a very promising technology for sustainable intensification of RW systems in the drought prone area of Bangladesh.
\end{abstract}

\section{Introduction}

Land degradation and soil fertility declining are among the main causes of the stagnation and fall of agricultural productivity in many tropical countries including those with intensive irrigated cropping systems. Approximately $85 \%$ of the area planted with intensive rice-wheat (RW) sequential cropping is found in the Indo-Gangetic Plain (IGP) of South Asia in India, Pakistan, Nepal and Bangladesh (Timsina and Connor, 2001). Rice is transplanted in flat fields are typically ponded for long periods or continuously from transplanting until shortly before harvest. This negatively affects soil properties for the following non-puddle crop (Hobbs ad Giri, 1998). Wheat is then planted in these structurally disturbed soils, often after many tillage operations to get the prepared the seedbed or increasingly, with little soil disturbance using zero-till seed drills. A change from growing crops on the flat to raised beds offers more effective control of irrigation water and drainage. This may be particularly beneficial for non-rice crops grown in rotation with rice, allowing better rainwater management during the monsoon season for rice. Connor et al. (2003) suggested that permanent raised beds might offer the farmers further significant advantages related to increased opportunities for crop diversification, mechanical weeding and placement of fertilizers, relay cropping and inter-cropping, and reduced tillage and water saving. There are also indications that crop yields from beds can be further increased by using higher rates of $\mathrm{N}$ fertilizer and later irrigation because of the reduced risk of lodging (Sayre and Ramos, 1997). Raised beds are increasingly used in many developed and developing countries in mechanized agriculture but have been 
Hossain et al.

introduced only recently in Bangladesh, with the aim of improving system productivity (Talukder et al., 2002).

Inclusion of grain legumes in the dry-wet transition of rice-wheat cropping system as a third crop may be the other option of increasing cropping intensity, soil fertility and productivity of the system. Although the non rice season across the rice-wheat area is characterized with low rainfall, heavy pre-monsoonal rain can have disastrous effects on the third crop, such as maize or mungbean grown after wheat or before rice, both during establishment and grain filling causing water logging (Timsina and Connor, 2001; Quayyum et al., 2002). Due to lack of crop establishment technique and temporary water logging at reproductive stage, inclusion of a grain legume like mungbean in rice-wheat cropping system very often faces problem. Bed planting may be a solution of this problem because raised beds not only facilitates irrigation but also drainage and therein lays their potential to increase the productivity of crops other than rice in the system. Growing leguminous crops in a cropping system is beneficial not only for economic products but also for soil amelioration (Singh et al., 1993). The common practice of rice in puddle soils destroys the soil physical structure that has implications for the following wheat crop (Hobbs et al., 2000). Crop residues are an important source of soil organic matter vital for the sustainability of agricultural ecosystems. About $25 \%$ of $\mathrm{N}$ and P, $50 \%$ of S and $75 \%$ of $\mathrm{K}$ uptake by cereal crops is retained in crop residues, making them valuable nutrient sources (Singh, 2003). However, straw retention is not a common practice in the RW systems of Bangladesh. Wheat and rice straw are usually removed from fields for use as cattle feed and thatching material for houses or for fuel, leaving little for incorporation into the soil. As a result, soil organic matter levels have declined in these cropping systems, and optimization of nutrient uptake and absorption efficiency.

In a study Talukder et al. (2002) found that $\mathrm{N}$ use efficiency was the highest in permanent raised beds, giving higher yields than a conventional system. Limon-Ortega et al. (2000) observed that permanent beds with straw retention had the highest mean wheat grain yields $\left(5.57 \mathrm{t} \mathrm{ha}^{-1}\right), \mathrm{N}$ use efficiency $(28.2 \mathrm{~kg}$ grain $\mathrm{kg}^{-1}$ of $\mathrm{N}$ supply) and total $\mathrm{N}$ uptake (133 kg ha-1), with positive implications for soil health. Thus, management of crop residues and beds, along with efficient $\mathrm{N}$ fertilization strategies are new farming practices that can increase and maintain yields from the intensive RW system in Bangladesh. Therefore, this study was undertaken in a drought prone area in north-western part at Rajshahi to evaluate the system productivity, soil fertility and $\mathrm{N}$ use efficiency of intensive wheat-mungbean-rice crops sequence tested on permanent raised bed (PRB) compared to conventionally tilled systems.

\section{Materials and Methods}

Wheat (Triticum aestivum)- mungbean (Vigna radiata)- monsoon rice (Oryza sativa) cropping pattern was followed for 8 times, at the Regional Wheat Research Centre, Shyampur, Rajshahi, Bangladesh $\left(24^{\circ} 3^{\prime} \mathrm{N}, 88^{0} 41 \mathrm{E}, 18 \mathrm{~m}\right.$ above sea level). The site has a subtropical climate and is located in Agro Ecological Zone 1 (Old Himalayan Piedmont Plains) on flood-free high land, with course-textured, highly permeable soil (BARC, 1997). The area receives $1,757 \mathrm{~mm}$ mean annual rainfall, about $97 \%$ of which occurs from May to September. Total rainfall was the highest during the mungbean season and the lowest in the wheat season in all years (Table 1).

The trial involved a three-crop sequence i.e., rice-wheat-mungbean (RWM) planted on raised beds and conventional. Rice was transplanted (one 25-day-old seedlings per hill) with spacing $30 \mathrm{~cm} \mathrm{x} 15 \mathrm{~cm}$ in late July and harvested in late November by hand. Wheat was seeded with 100 and $120 \mathrm{~kg} \mathrm{seed} \mathrm{ha}^{-1}$ for beds and conventional, respectively, in late November and harvested in late March. After harvest of wheat, mungbean were planted in March with seeding rate of $35 \mathrm{~kg} \mathrm{ha}^{-1}$ in early April and harvested in mid July for both beds and conventional. The trial was originally established as a PRB experiment with two straw management practices (main plots-30\% straw retention (SR) and $0 \% \mathrm{SR}$ ) and five $\mathrm{N}$ levels (subplots $0,40,80,100$ and $120 \%$ of recommended). The area of each subplot was $15 \mathrm{~m}^{2}$ (5m x 3m). The 
Bed Planting Effect of Rice and Wheat in Drought Prone Area

experiment consisted of 20 subplots with four tillage/straw treatments (30\% SR + PRB, 30\% SR + CTP, $0 \%$ SR + PRB and 0\% SR + CTP) and five N levels (0, 40, 80, 100 and 120\% of recommended) with three replication. After planting the wheat or rice, straw from the preceding cereal crops was returned as a mulch into the plot from which it had been removed at harvest. After harvesting and threshing, the rice and wheat straw were returned without chopping as standing way.

The width of the beds was $60 \mathrm{~cm}$ (furrow to furrow) and the depth of the furrows on average was $15 \mathrm{~cm}$. Two rows of wheat (var. Shatabdi) or rice (var. BRRI dhan 49) with a spacing of $30 \mathrm{~cm}$, were planted by hand sowing on the beds, two rows of rice on the beds, Mungbean (var. BARI Mungbean-6) was sown by bed former in the furrows between the beds. The mungbean was harvested about 60 days after sowing (DAS). In CTP, wheat, rice and mungbean were planted in $20 \mathrm{~cm}, 30 \times 15 \mathrm{~cm}$ and $30 \mathrm{~cm}$ in continuous rows. A basal dose of $P\left(20,22\right.$ and $\left.26 \mathrm{~kg} \mathrm{ha}^{-1}\right)$ from triple super phosphate, $\mathrm{K}\left(15,35\right.$ and $\left.33 \mathrm{~kg} \mathrm{ha}^{-1}\right)$ from muriate of potash and $S\left(10,11\right.$ and $\left.20 \mathrm{~kg} \mathrm{ha}^{-1}\right)$ from gypsum was applied to mungbean, rice and wheat, respectively. In rice the entire amount of PKS was broadcasted before transplanting and mulching on both PRB and CTP. For CTP the fertilizer was broadcast before tillage as is the usual practice. The recommended rate of $\mathrm{N}$ (80 kg ha ${ }^{-1}$ for rice, $100 \mathrm{~kg} \mathrm{ha}^{-1}$ for wheat and $20 \mathrm{~kg} \mathrm{ha}^{-1}$ for mungbean) was applied as urea. For mungbean all $\mathrm{N}$ was applied before seeding. With CTP, N was broadcast, while with beds it was banded on top of the soil between two rows in three equal installments 15, 30 and 45 days after transplanting, while wheat, two-thirds of the $\mathrm{N}$ was applied before seeding and the remaining onethird at crown root initiation (CRI). Sufficient irrigation water was applied to fill the furrows between the raised beds.

\section{Total system productivity}

Total system productivity (TSP) was calculated using the method of Tanaka (1983). Based on the composition of harvested organs for mungbean and their conversion efficiencies, the equivalent yields for various crops can be calculated (Tanaka, 1983). Total system productivity (TSP) for each treatment was calculated as the total annual productivity (or the annual total of economic yield of the individual crops) based on equivalent yields.

\section{Estimation of nitrogen uptake}

The result was expressed in percentage. $\mathrm{N}$-uptake by grain and straw also were calculated by the following formulae:

$\mathrm{N}$-uptake by grain $\left(\mathrm{kg} \mathrm{ha}^{-1}\right)=$ Total $\mathrm{N}(\%)$ in grain $\mathrm{x}$ grain yield $\left(\mathrm{kg} \mathrm{ha}^{-1}\right)$

100

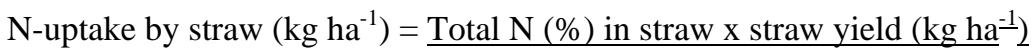

100

\section{Different measures of nitrogen use efficiency}

The different measures of N-use efficiencies; physiological efficiency (PE), fertilizer recovery efficiency (RE), and agronomic efficiency (AE) were calculated as described by Dobermann and Fairhurst (2000). Total $\mathrm{N}$ uptake as used in this term referred to $\mathrm{N}$ uptake by above ground biomass (grain and straw) only Recovery efficiency (RE) of added $\mathrm{N}$ was calculated as:

$$
\mathrm{RE}(\%)=\frac{\text { Total } \mathrm{N} \text { uptake }\left(\mathrm{kg} \mathrm{N} \mathrm{ha}^{-1}\right) \text { of the treatment - total } \mathrm{N} \text { uptake }\left(\mathrm{kg} \mathrm{N} \mathrm{ha}^{-1}\right) \text { of the control }}{\text { Applied } \mathrm{N}\left(\mathrm{kg} \mathrm{N} \mathrm{ha}^{-1}\right) \text { of the treatment }} \times 100
$$

Physiological efficiency (PE) of added $\mathrm{N}$ was calculated as:

$\begin{array}{ll}\mathrm{PE}\left(\mathrm{kg} \text { grain } \mathrm{kg}^{-1}\right. & \text { Grain yield }\left(\mathrm{kg} \mathrm{ha}^{-1}\right) \text { of the treatment }- \text { grain yield }\left(\mathrm{kg} \mathrm{ha}^{-1}\right) \text { of the control } \\ \mathrm{N} \text { uptake })= & \text { Total } \mathrm{N} \text { uptake }\left(\mathrm{kg} \mathrm{N} \mathrm{ha}^{-1}\right) \text { of the treatment }- \text { total } \mathrm{N} \text { uptake }\left(\mathrm{kg} \mathrm{N} \mathrm{ha}^{-1}\right) \text { of the control }\end{array}$


Hossain et al.

Agronomic efficiency (AE) of added $\mathrm{N}$ was calculated as:

$$
\begin{aligned}
& \mathrm{AE}\left(\mathrm{kg} \text { grain } \mathrm{kg}^{-1} \quad \text { Grain yield }\left(\mathrm{kg} \mathrm{ha}^{-1}\right) \text { of the treatment }- \text { grain yield }\left(\mathrm{kg} \mathrm{ha}^{-1}\right)\right. \text { of the control } \\
& \text { applied })=
\end{aligned}
$$

\section{Statistical analysis of data}

The data were analyzed statistically following computer package MSTAT and the significance of mean differences was adjusted by Duncan’s Multiple Range Test.

\section{Results and Discussion}

\section{Total system productivity (TSP)}

TSP increased by 12-15\% with 30\% straw retention with PRB (12 $\left.\mathrm{t} \mathrm{ha}^{-1} \mathrm{yr}^{-1}\right)$ compared with CTP with 0\% straw retention (Fig. 1). For all crops the highest system yields obtained in PRB $+30 \%$ SR. Yields on PRB consistently increased significantly as SR increased from $0 \%$ to 30 . The lower system productivity with $0 \%$ SR with CTP was associated with reduced crop growth. Similar observations were made by Singh et al. (2003) in Mexico.

Fig. 2 presents the system yields of different tillage options and $\mathrm{N}$ levels (means of three years), illustrating that TSP increased significantly by $11 \%$ in rice and $14 \%$ in mungbean with increasing $\mathrm{N}$ levels up to $100 \%$; and by $16 \%$ in wheat up to $120 \% \mathrm{~N}$. For all crops the highest system productivity occurred in PRB with $120 \% \mathrm{~N}$ (120 kg N ha ${ }^{-1}$ in wheat) and $80 \% \mathrm{~N}$ both in rice and mungbean $(80 \mathrm{~kg} \mathrm{~N}$ $\mathrm{ha}^{-1}$ in rice, $20 \mathrm{~kg} \mathrm{~N} \mathrm{ha}^{-1}$ in mungbean). Yields tended to be lower with lower nitrogen levels for all crops. Similar observations were made by Yadvinder et al. (2006) in India. Averaged over the years, PRB + 30 $\%$ SR with $100 \% \mathrm{~N}$ gave a $17 \%$ increase in wheat yield over PRB + $0 \%$ SR at the same $\mathrm{N}$ rate, but there was no significant mungbean yield increase with additional $\mathrm{N}$ with $30 \% \mathrm{SR}$. However, yield of PRB + 30\% SR with $120 \% \mathrm{~N}$ was significantly higher than PRB + $0 \%$ SR with $100 \% \mathrm{~N}$ in wheat. Average rice yield on PRB $+30 \%$ SR with $50 \% \mathrm{~N}$ was significantly higher than with $0 \%$ SR at the same $\mathrm{N}$ rate, and there was no further yield increase at higher $\mathrm{N}$ rates. Rice yield declined with $30 \% \mathrm{SR}$ at the two highest $\mathrm{N}$ rates, mostly due to lodging.

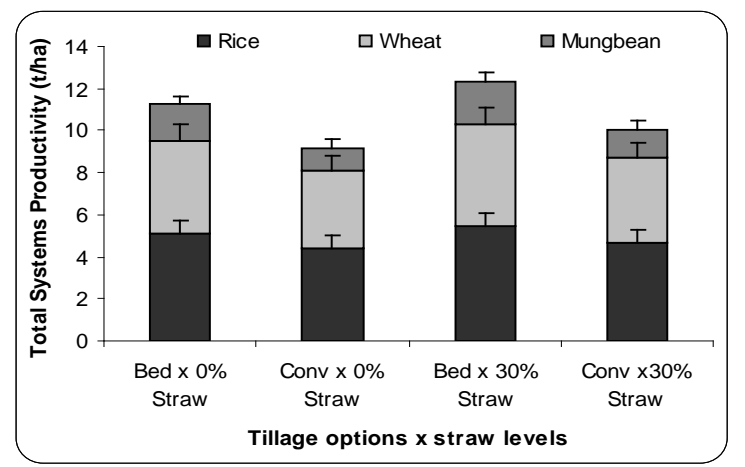

Fig 1. Total system productivity under tillage options and straw levels in rice-wheatmungbean system

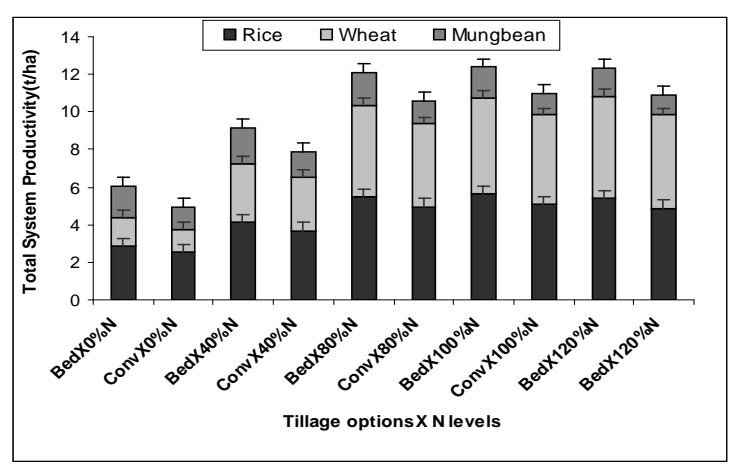

Fig. 2. Total system productivity under tillage options nitrogen levels in rice-wheatmungbean systems

Lower system productivity also occurred from $0 \% \mathrm{~N}$ with CT due to less $\mathrm{N}$ uptake and use efficiency. Yields tended to be lower in differences of nitrogen levels for all crops. Similar observations were made 
Bed Planting Effect of Rice and Wheat in Drought Prone Area

by Yadvinder et al. (2006) in India. Yields tended to be lower in differences at four N levels in wheat, at three $\mathrm{N}$ levels in rice and at two lowest $\mathrm{N}$ levels in mungbean (Fig. 2). Averaged over the 7 years, PRB + $30 \%$ SR with $100 \% \mathrm{~N}$ gave $17 \%$ increased in wheat yield over PRB + $0 \%$ SR at the same $\mathrm{N}$ rate (Fig. 2). However, yield of PRB $+30 \%$ SR with $120 \% \mathrm{~N}$ was significantly higher than PRB $+0 \%$ SR with $100 \% \mathrm{~N}$. Average rice yield on PRB $+30 \%$ SR with 50\% N was significantly higher than with $0 \%$ SR at the same $\mathrm{N}$ rate, and there was no further yield increase at higher $\mathrm{N}$ rates, Rice yield declined with $30 \%$ $\mathrm{SR}$ at the two highest $\mathrm{N}$ rates, mostly due to lodging.

Maximum average wheat grain yield was obtained on PRB from $120 \% \mathrm{~N}$ with $30 \%$ SR and after 7 years yield was similar when $80 \% \mathrm{~N}$ with $30 \%$ straw retention (Fig. 2). These yield increases with straw retention are probably due to suppression of soil evaporation, less weeds and more efficient use of fertilizers. Limon-Ortega et al. (2000) reported that permanent beds both wheat and maize yields when grown with higher rates of $\mathrm{N}$ fertilizer. Rice yield was comparatively low under the CTP system due to water logging and the resultant acute weed stress (poor crop growth could not compete as well with weeds) in early as well as late growth stages. Variability in wheat yields in Bangladesh is mostly the result of the high temperature that can occur during the grain filling phase, especially for late-sown crops (Midmore et al., 1984).

\section{Nitrogen uptake and use efficiency}

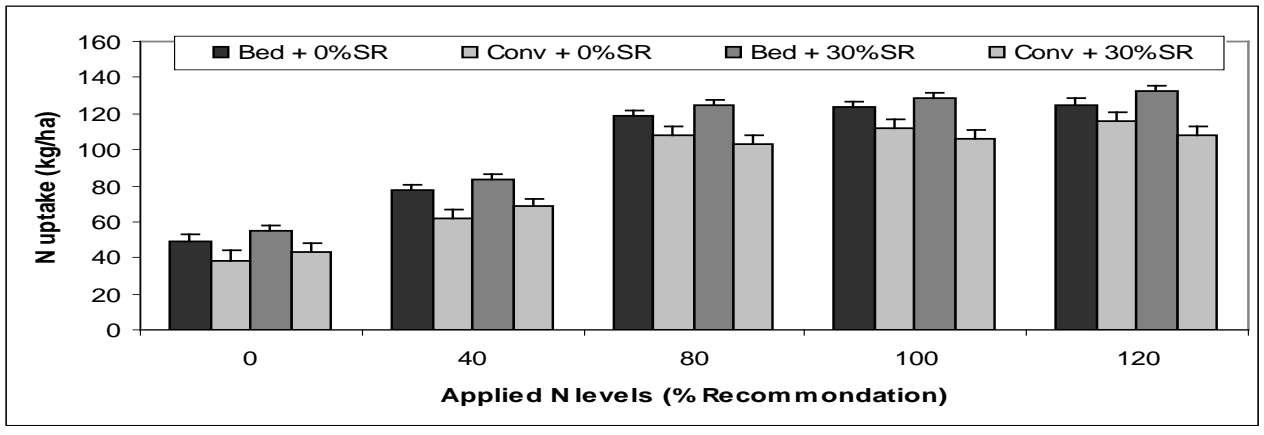

Fig. 3. Total nitrogen uptake under tillage options, straw and nitrogen levels in ricewheat-mungbean systems

Total $\mathrm{N}$ uptake increased with increasing up to $120 \%$ and it was similar as $80 \%$ in all crops. The increased $\mathrm{N}$ uptake was 31\% in rice, $25 \%$ in wheat and $19 \%$ in mungbean over conventional (Fig. 3). Retention of straw resulted in increased $\mathrm{N}$ uptake in both $\mathrm{N}$ fertilized and zero $\mathrm{N}$ plots. Nitrogen uptake was significantly $(\mathrm{P}<0.5)$ influenced by straw retention and $\mathrm{N}$ level. In $\mathrm{PRB}+30 \% \mathrm{SR}$ plots, total $\mathrm{N}$ uptake by rice was maximum at $50-100 \%$ by rice, $80-120 \%$ by wheat and $50-100 \%$ by mungbean. In contrast, in both PRB and CTP without straw retention, there was a consistent trend for increasing $\mathrm{N}$ uptake up to $120 \% \mathrm{~N}$ rate in all crops. Limon-Ortega et al. (2000) also observed that permanent beds with straw retention gave the highest wheat grain yields (5057 $\left.\mathrm{tha}^{-1}\right), \mathrm{N}$ use efficiency (28.2 $\mathrm{kg}_{\text {grain }} \mathrm{kg}^{-1}$ of $\mathrm{N}$ supply) and total $\mathrm{N}$ uptake (133 $\left.\mathrm{kg} \mathrm{ha}^{-1}\right)$. Yield in $\mathrm{N}$ unfertilized rice, wheat and mungbean increased when straw was retained and this appeared to be due to an increased uptake of N. Fertilizer use efficiency may be increased by implementing permanent bed management in addition to reducing weed and crop lodging problems. $\mathrm{N}$ use efficiency (calculated PE, AE and RE) decreased as $\mathrm{N}$ rate increased in all treatments (Table 1). At the lowest $\mathrm{N}$ rate there was a consistent trend for higher AE on PRB with $30 \%$ SR and $0 \%$ SR. There was a consistent trend for higher PE on PRB as the amount of SR increased from 0 to $100 \%$ across all crops. Similar observations were made by Yadvinder et al. (2004). They reported that AE was significantly higher in straw retained + green manure cultivated treatments than other treatments for wheat. $\mathrm{N}$ uptake helps the decomposition of retained straw, resulting in a higher uptake of nutrients and more efficient use of water. $\mathrm{N}$ use efficiencies increases rice life 3-5 days.

Table 1. Nitrogen use efficiency of rice, wheat and mungbean (2004-12) as influenced by straw retention, 
Hossain et al.

tillage and N level at Rajshahi, Bangladesh.

\begin{tabular}{|c|c|c|c|c|c|c|c|c|c|}
\hline \multirow[b]{2}{*}{ Treatments } & \multicolumn{3}{|c|}{$\mathrm{AE}\left(\mathrm{kg}\right.$ grain $\mathrm{kg}^{-1} \mathrm{~N}$ applied) } & \multicolumn{3}{|c|}{ PE (kg grain $\mathrm{kg}^{-1} \mathrm{~N}$ uptake) } & \multicolumn{3}{|c|}{$\mathrm{RE}(\%)$} \\
\hline & Rice & Wheat & Mungbean & Rice & Wheat & Mungbean & Rice & Wheat & Mungbean \\
\hline \multicolumn{10}{|c|}{$30 \% \mathrm{SR}+\mathrm{PRB}$} \\
\hline $\mathrm{N}_{0}$ & - & - & - & 64.5 & 44.5 & 49.5 & - & - & - \\
\hline $\mathrm{N}_{50}$ & 49.3 & 33.5 & 16.5 & 53.4 & 33.5 & 36.8 & 95.4 & 96.8 & 112.7 \\
\hline $\mathrm{N}_{100}$ & 41.2 & 24.3 & 10.6 & 45.8 & 26.2 & 32.3 & 89.8 & 81.7 & 106.3 \\
\hline $\mathrm{N}_{150}$ & 23.5 & 18.5 & 6.7 & 41.4 & 25.7 & 25.3 & 66.2 & 64.7 & 95.7 \\
\hline $\mathrm{N}_{200}$ & 20.2 & 14.5 & 3.9 & 38.2 & 23.4 & 22.4 & 50.9 & 45.2 & 77.6 \\
\hline \multicolumn{10}{|c|}{$0 \% \mathrm{SR}+\mathrm{PRB}$} \\
\hline $\mathrm{N}_{0}$ & - & - & - & 58.3 & 39.5 & 43.5 & - & - & - \\
\hline $\mathrm{N}_{50}$ & 42.3 & 28.3 & 12.8 & 49.8 & 29.5 & 31.5 & 87.8 & 84.5 & 95.3 \\
\hline $\mathrm{N}_{100}$ & 34.5 & 21.5 & 9.7 & 41.5 & 22.4 & 27.3 & 78.6 & 74.6 & 87.3 \\
\hline $\mathrm{N}_{150}$ & 21.3 & 14.3 & 6.3 & 38.9 & 18.5 & 22.5 & 58.6 & 62.5 & 82.1 \\
\hline $\mathrm{N}_{200}$ & 18.5 & 10.5 & 3.2 & 29.6 & 11.5 & 18.3 & 42.5 & 53.2 & 63.2 \\
\hline \multicolumn{10}{|c|}{$30 \% \mathrm{SR}+\mathrm{CTP}$} \\
\hline $\mathrm{N}_{0}$ & - & - & - & 59.6 & 44.5 & 44.5 & - & - & - \\
\hline $\mathrm{N}_{50}$ & 45.3 & 29.5 & 14.5 & 50.2 & 34.2 & 32.4 & 90.2 & 87.3 & 98.6 \\
\hline $\mathrm{N}_{100}$ & 38.5 & 22.3 & 10.2 & 43.2 & 25.3 & 28.3 & 82.3 & 77.3 & 89.3 \\
\hline $\mathrm{N}_{150}$ & 25.4 & 19.3 & 6.4 & 37.8 & 22.3 & 23.2 & 60.5 & 65.3 & 82.5 \\
\hline $\mathrm{N}_{200}$ & 20.3 & 12.4 & 3.4 & 30.5 & 13.5 & 19.7 & 44.5 & 53.4 & 68.5 \\
\hline \multicolumn{10}{|c|}{$0 \% \mathrm{SR}+\mathrm{CTP}$} \\
\hline $\mathrm{N}_{0}$ & - & - & - & 52.3 & 45.3 & 57.6 & - & - & - \\
\hline $\mathrm{N}_{50}$ & 38.7 & 24.1 & 12.6 & 49.6 & 33.7 & 43.5 & 82.7 & 81.3 & 97.2 \\
\hline $\mathrm{N}_{100}$ & 33.4 & 20.4 & 9.6 & 42.2 & 27.9 & 34.5 & 71.4 & 71.2 & 81.4 \\
\hline $\mathrm{N}_{150}$ & 19.2 & 16.2 & 6.4 & 37.5 & 26.8 & 30.9 & 48.9 & 59.6 & 71.6 \\
\hline $\mathrm{N}_{200}$ & 14.7 & 9.9 & 2.6 & 33.2 & 24.8 & 24.3 & 39.2 & 44.3 & 58.5 \\
\hline
\end{tabular}

$\mathrm{PRB}=$ permanent raised beds, $\mathrm{SR}=$ straw retention; $\mathrm{CTP}=$ conventional tillage practice

\section{Soil organic matter (SOM)}

After 8 years (2004-12), retention of straw from all three crops in the zero-till PRB system had increased the soil organic matter by $0.72 \%$ (Table 2 ). While some of the increase may have been due to formation of the beds from topsoil, the change in organic $\mathrm{C}$ increased as the rate of residue retention increased from $100 \%$, indicating that straw retention also affected organic $C$ on the beds. $30 \%$ SR with PRB, P, K and Zn availability increased. At low $\mathrm{N}$ levels ( 0 and $50 \%$ of recommended) there appeared to be a slight decline in soil organic C. After 8 years of CTP without residues, soil organic C had decreased by a few percent at all $\mathrm{N}$ rates and there was a consistent trend for a large decline at lower $\mathrm{N}$ rate. The increase in soil organic C with 30\% SR at 50-150\% N was almost double that with $0 \%$ N. Kumar and Goh (2000) reported that, in the longer term, residues and untilled roots from crops can contribute to the formation of SOM. After the seven RWM crop cycles, the soil color had darkened, presumably due to the build-up of organic matter in the topsoil (Fig. 4).

Table 2. Chemical properties changes in soil for 30\% straw from 2004-2012

\begin{tabular}{|c|c|c|c|c|}
\hline Bed x $0 \%$ Straw & $\begin{array}{c}\text { Bed x } 0 \% \\
\text { straw }\end{array}$ & Conv. x $0 \%$ straw & Bed x $30 \%$ straw & Conv. x 30\% Straw \\
\hline $\mathrm{pH}$ & 8.2 & 8.3 & 7.7 & 7.9 \\
\hline OM (\%) & 1.06 & 1.06 & 1.78 & 1.24 \\
\hline Total N (\%) & 0.11 & 0.12 & 0.09 & 0.11 \\
\hline $\mathrm{P}\left(\mathrm{mg} \mathrm{g}^{-1}\right.$ soil $)$ & 15.12 & 14.5 & 19.87 & 16.75 \\
\hline $\mathrm{K}$ ml (eq $100 \mathrm{~g}^{-1}$ soil) & 0.37 & 0.39 & 0.48 & 0.43 \\
\hline
\end{tabular}


Bed Planting Effect of Rice and Wheat in Drought Prone Area

\begin{tabular}{lcccc}
$\mathrm{S}\left(\mathrm{mg} \mathrm{g}^{-1}\right.$ soil) & 17.25 & 24.2 & 15.85 & 21.27 \\
$\mathrm{Zn}\left(\mathrm{mg} \mathrm{g}^{-1}\right.$ soil $)$ & 0.23 & 0.12 & 0.37 & 0.17 \\
$\mathrm{~B}\left(\mathrm{mg} \mathrm{g}^{-1}\right.$ soil) & 0.31 & 0.21 & 0.35 & 0.24 \\
$\mathrm{EC}\left(\mathrm{dS} \mathrm{m}^{-1}\right)$ & 0.97 & 1.24 & 0.92 & 1.17 \\
\hline
\end{tabular}

Table 3. Soil chemical properties changes for $30 \%$ straw retention after eight years

\begin{tabular}{|c|c|c|c|}
\hline Characteristics & Initial & Final & Difference \\
\hline $\mathrm{pH}(1: 2.5$ in water) & 8.3 & 8.0 & -0.3 \\
\hline Organic Matter (\%) & 1.10 & 1.82 & +0.72 \\
\hline Total N (\%) & 0.12 & 0.09 & -0.03 \\
\hline Exch. K (ml eq $100 \mathrm{~g}^{-1}$ soil) & 0.26 & 0.48 & +0.22 \\
\hline Avail. P (mg g ${ }^{-1}$ soil) & 24.5 & 52.5 & +38.0 \\
\hline Avail. S (mg g ${ }^{-1}$ soil) & 25.6 & 38.9 & +13.3 \\
\hline Avail. Zn (mg g ${ }^{-1}$ soil) & 0.84 & 6.13 & +5.29 \\
\hline Avail. B (mg g ${ }^{-1}$ soil) & 0.19 & 0.37 & +0.18 \\
\hline Ca (ml eq $100 \mathrm{~g}^{-1}$ soil) & 18.22 & 21.24 & +3.02 \\
\hline $\operatorname{Mg}\left(\mathrm{ml}\right.$ eq $100 \mathrm{~g}^{-1}$ soil) & 5.05 & 6.17 & +1.12 \\
\hline $\mathrm{Fe}\left(\mathrm{mg} \mathrm{g}^{-1}\right.$ soil $)$ & 76.4 & 63.5 & -12.9 \\
\hline $\operatorname{Mn}\left(\mathrm{mg} \mathrm{g}^{-1}\right.$ soil) & 22.9 & 12.7 & -10.2 \\
\hline
\end{tabular}

\section{Economic Evaluation of Conservation Agriculture (CA)}

For economic evaluation, considered 20 farmers for permanent bed and 25 farmers for new bed in both the cases. From Table 4, observed that total 25\% cost saved of T. Aman rice production in PRB and 17\% cost saved in new bed over farmers practice as well as more than double net return from both permanent and new bed system over farmers practice (FP). It also observed that economically higher return from both PRB (28\%) and new beds (34\%) than FP. However, CA is more economically viable than FP.

Table 4. Economic Performance of CA for T Aman rice in 2010-12 from farmers

\begin{tabular}{|c|c|c|c|c|c|c|}
\hline \multirow[t]{2}{*}{ Factors } & \multicolumn{3}{|c|}{ Permanent $(n=20)$} & \multicolumn{3}{|c|}{ New $(n=25)$} \\
\hline & Bed & FP & Change & Bed & $\mathrm{FP}$ & Change \\
\hline Tillage / land preparation & 250 & 480 & $-47 \%$ & 480 & 480 & \\
\hline Seed & 140 & 200 & $-30 \%$ & 140 & 200 & $-30 \%$ \\
\hline Fertilizer \& Pest management & 650 & 780 & $-16 \%$ & 650 & 780 & $-16 \%$ \\
\hline Irrigation & 450 & 760 & $-40 \%$ & 480 & 760 & $-36 \%$ \\
\hline Weeding & 395 & 550 & $-26 \%$ & 420 & 550 & $-23 \%$ \\
\hline Harvest & 510 & 560 & $-9 \%$ & 520 & 560 & $-7 \%$ \\
\hline Threshing & 230 & 200 & & 230 & 200 & \\
\hline Total Costs & 2625 & 3530 & $-25 \%$ & 2920 & 3530 & $-17 \%$ \\
\hline Yield (kg bigha ${ }^{-1}$ ) & 760 & 590 & $28 \%$ & 795 & 590 & $34 \%$ \\
\hline Value@Tk10kg-1 & 7600 & 5900 & $28 \%$ & 7950 & 5900 & $34 \%$ \\
\hline Net Return & 4975 & 2370 & $\begin{array}{c}2605 \\
(2.1 X)\end{array}$ & 5030 & 2370 & $2660(2.12 X)$ \\
\hline
\end{tabular}

\section{Conclusion}

Retention of $30 \%$ crop residues together with zero-till permanent bed system offers an important soil restorative management strategy likely to have a long-term positive impact on soil quality and crop productivity in intensive rice-wheat-mungbean (RWM) cropping systems in Bangladesh. Besides, residual straw and roots added more organic matter and nutrients into the soils under PRB, resulting in increased nutrient uptake by the crops. Crop productivity on beds with $30 \%$ straw retention increased by 
Hossain et al.

$11 \%$ for rice, $17 \%$ for wheat and $21 \%$ for mungbean at $100 \% \mathrm{~N}$ rates over a 7 year cycle of the RWM cropping pattern compared with $0 \% \mathrm{SR}+\mathrm{PRB}$ at the same $\mathrm{N}$ rate. Yield in $\mathrm{N}$ unfertilized rice, wheat and mungbean increased when straw was retained and this appeared to be due to an increased uptake of $\mathrm{N}$. Retention of crop residues as a mulch reduced moisture depletion and increased SOM content over relatively short periods of time. Fertilizer use efficiency may be increased by implementing permanent bed management in addition to reducing weed and crop lodging problems. Permanent raised beds would also help ameliorate the adverse effects of tillage on soil structure, which might lead to water logging under excess water conditions and hamper establishment, growth and development of most crops including mungbean. The use of PRB reduces the overall cost of production and long turnaround time. Thus, results showed that PRB with straw retention could help to intensify RW systems to RWM systems under high degrees of management as such further on-farm adaptive trial with farmers is needed to verify the technology.

\section{Acknowledgement}

We acknowledge the International Wheat and Maize Improvement Centre (CIMMYT) for financial support for conducting this study.

\section{References}

Gomez, K. A. and A. A. Gomez. 1984. Statistical Procedures for Agricultural Research (Second edition).John Wiley \& Sons, Inc., IRRI, Philippines, 680p.

Govaerts B, K. D. Sayre and J. Deckers. 2006. Towards minimum data sets for soil quality assessment. The case of zero-tillage wheat/maize rotations in the highland of Mexico. Soil Till. Res. 87: 163-174.

Gupta, R. K., R. K. Naresh, P. R. Hobbs and J. K. Ladha. 2002. Adopting Conservation Agriculture in RiceWheat Systems of the Indo-Gangetic Plains- New Opportunities for Saving on Water. Paper presented at the "Water Wise Rice Production Workshop", 5-10 April 2002, IRRI, Philippines.

Hobbs, P. R and R. K Gupta. 2000. 'Soil and Crop Management Practices for Enhanced Productivity of the RiceWheat Cropping System in the Sichuan Province of China'. Rice-Wheat Consortium Paper Series 9. (RWC, New Delhi, India).

IPPC. 2007. Fourth Assessment Report of the Intergovernmental Panel on Climate Change: The Impacts, adaptation and vulnerability. Cambridge University Press, United Kingdom and New York, NY, USA.

Kataki, P. K. 2001. The rice-wheat cropping system in South: Trends, Constraints and Productivity- A Prologue, J. Crop Prod. 3: 1-26.

Kumar, K. and K. M. Goh. 2000. Crop residue management, effects on soil quality, soil nitrogen dynamics, crop yield and nitrogen recovery. Adv. Agron. 68: 197-319.

Lauren, J. G., J. M. Duxbury, M. I. Hossain, G. Sah, A. S. M. H. M. Talukder and C. A. Meisner. 2006. Permanent raised bed cultivation improves nitrogen and water use in rice-wheat cropping systems of South Asia. $18^{\text {th }}$ World Science Congress, USA.

Limon-Ortega, A. L., K. D. Sayre and C. A. Francis. 2000a. Wheat nitrogen use efficiency in a bed planting system in Northwest Mexico. Agron. J. 92: 303-308.

Limon-Ortega, A., K. D. Sayre and C. A. Francis. 2000b. Wheat and maize yields in response to straw management and nitrogen under a bed planting system. Agron. J. 92: 295-302.

Quayyum, M. A., J. Timsina, M. A. H. S. Jahan, R. A. Begum and D. J. Connor. 2002. Grain yield and system productivity for wheat-mungbean-rice and wheat-maize rice sequences in northern Bangladesh. Thai J. Agric. Sci. 35: 51-62. 
Bed Planting Effect of Rice and Wheat in Drought Prone Area

RWC-CIMMYT. 2003. Addressing Resource Conservation Issues in Rice-Wheat Systems of South Asia: A Resource Book. (RWC-CIMMYT, New Delhi, India).

Sayre, K. D., A. Limon, and B. Govaerts. 2005. Experiences with permanent bed planting systems. In: Roth, C. H., Fischer, R. A., Meisner, C. A. (Eds.). Evaluation and Performance of Permanent Raised Bed Cropping Systems in Asia, Australia and Mexico, Proceedings of a Workshop, Griffith, Australia, 1-3 March 2005. ACIAR Proceedings No. 121, pp.12-25.

Singh, Y. 2003. Crop Residue management in rice-wheat system. 2003. In: Addressing Resource Conservation Issues in Rice-Wheat Consortium for the Indo-Gangetic Plains. CIMMYT, New Delhi, India, p.153.

Singh, H., and K. P. Singh. 1995. Effect of plant residue and fertilizer on grain yield of dryland rice under reduced tillage cultivation. Soil Till. Res. 34: 115-125.

Tanaka, A. 1983. Physiological aspects of productivity in field crops. In: Potential Productivity of Field Crops Under Different Environments. IRRI, Los Banos, Philippines, pp.61-80.

Talukder, A. S. M. H. M., C. A. Meisner, M. J. Kabir, A. B. S. Hossain and M. Harun-ur-Rashid. 2004. Productivity of multi-crops sown on permanent raised beds in the tropics. In: New Direction for a Diverse Planet: Handbook and Abstracts for the $4^{\text {th }}$ International Crop Science Congress, Brisbane, Australia, 26 September - 01 October 2004, p.173.

Talukder, A. S. M. H. M., M. A. Sufian and C. A. Meisner. 2002. Rice, wheat and mungbean yields in response to $\mathrm{N}$ levels and management under a bed planting system. In: Proceedings published in the $17^{\text {th }}$ World Congress of Soil Science, Bangkok, Thailand, v. 1, Symposium no. 11, p.351.

Timsina, J. and D. J. Connor. 2001. Productivity and management of rice-wheat cropping systems: issues and challenges. Field Crops Res. 69: 93-132.

Witt, C., K. G. Cassman, D, C. Olk, U. Biker, S. P. Liboon, M. I. Samson and J. C. G. Ottow. 2000. Crop rotation and residue management effects on carbon sequestration, nitrogen cycling and productivity of irrigated rice systems. Plant Soil. 225: 263-278.

Yadvinder, S., S. Bijay, and J. Timsina. 2005. Crop residue management for nutrient cycling and improving soil productivity in rice-based cropping systems in the tropics. Adv. Agron. 85: 269-407.

Yadvinder, S., S. Bijay, J. K. Ladha, C. S. Khind and T. S. Kera. 2006. Effects of residue decomposition on productivity and soil fertility in rice-wheat rotation. Soil Sci. Soc. Amer. J. 68: 851-864. 